\title{
Samsun İli Terme ve Kocaman Irmağı'ndan alınan çevresel su örneklerinde su kökenli parazitlerin tespit edilmesi
}

\author{
Zeynep KOLÖREN ${ }^{1}$, Ülkü KARAMAN²
}

10rdu Üniversitesi, Fen Edebiyat Fakültesi, Biyoloji Bölümü, ORDU

${ }^{2}$ Ordu Üniversitesi, Tıp Fakültesi, Parazitoloji Bölümü, ORDU

Alınış tarihi: 3 Mayıs 2017, Kabul tarihi: 9 Ekim 2017

Sorumlu yazar: Zeynep KOLÖREN, e-posta: zeynep.koloren@yahoo.com

Öz

$\mathrm{Bu}$ çalışmanın amacı, Samsun'un Terme ilçesinde bulunan Terme ve Kocaman Irmağı'ndan belirlenen altı istasyondan alınan çevre suyu örneklerinde Cryptosporidium spp., Giardia spp. ve Toxoplasma gondii'nin varlığının Nested Polimeraz Zincir Reaksiyonu (N-PZR) ve İmmünfloresan yöntemi (IFA) ile saptanmasıdır. Çalıșmada toplanan su örnekleri Alüminyum sülfat ile çöktürülerek Sukroz gradiyent yöntemiyle saflaştırılmıştır. Bunu takiben, su örneklerine ait pelletler hem IFA hemde DNA izolasyonunda kullanılmıștır. Alınan 72 çevresel su örneğinin 60'ında (\%83.3) 1-19 ookist/L Cryptosporidium spp. ookistlerinin; 48'inde (\%66.6) 1-13 kist/L Giardia spp. kistlerinin varlığ IFA ile tespit edilmiştir. IFA yöntemi ile pozitif bulunan su örneklerinin hepsi N-PZR tekniği ile de doğrulanmıştır. Ayrıca çalışmada alınan su örneklerinde T. gondii'nin varlığl yine N-PZR tekniğiyle araştırılmış ve Kocaman Irmağı'ndaki üç istasyonun da bu parazitle kontamine olduğu görülmüştür. Su kaynaklı parazitlere ait kist ve ookistlerin hayvan dışkısı ve kanalizasyon yolu ile yüzeysel sulara taşındığı bilinmektedir. Elde edilen sonuçlar bölgenin bu parazitlerle kontamine olduğunu göstermiştir. Sonuç olarak su kaynaklı paraziter enfeksiyonlar yönünden, kontamine suların bir risk faktörü olduğu dikkate alınarak, su kaynaklarının düzenli bir şekilde kontrol edilmesinin uygun olacağı kanaatine varılmıştır.

Anahtar kelimeler: Cryptosporidium spp., Giardia spp., Toxoplasma gondii, su kirliliği, Terme ve Kocaman Irmağ
Determination of waterborne parasites in environmental water samples collected from Terme and Kocaman Rivers in Samsun province of the Black Sea Region

\section{Abstract}

In the study, it was aimed to determine the presence of Cryptosporidium spp., Giardia spp., and T. gondii by Nested Polymerase Chain Reaction (N-PCR) and Immunofluorescence Assay (IFA) in the environmental water samples collected from Terme and Kocaman River in Terme borough of Samsun in Black Sea. The collected water samples were concentrated by Aliminium sulfate flocculation and they were purified by sukroz gradient. Subsequently, pellets of water samples were used for both IFA and DNA isolation. Sixty $(83.3 \%)$ and $48(66.6 \%)$ of 72 environmental water samples were found to be positive with 1-19 oocysts/L for Cryptosporidium spp. and 1-13 cysts/L for Giardia spp. by the IFA. All of the water samples found positive by IFA were confirmed using N-PCR. In addition, the presence of T. gondii in the water samples was investigated using the N-PCR as well and all three stations were found to be contaminating with this parasite. It is known that cysts and oocysts of waterborne parasites are transported to surface waters by animal wastes and sewage. According to the obtained results, it is observed that the investigated area is contaminating with this parasites. As a result, considering that contaminated water are a risk factor for parasitic infections, it is recommended that water resources should be controlled regularly.

Key words: Cryptosporidium spp., Giardia spp., Toxoplasma gondii, water pollution, parasite, Terme and Kocaman Rivers 


\section{Giriş}

İnsan ve hayvan sağlığını tehdit eden Cryptosporidium parvum, Giardia intestinalis ve Toxoplasma gondii su kaynaklı parazitler arasında yer almaktadır. Oral-fekal yolla bulaştı̆̆ bilinen bu parazitlerin hastalık oluşturabilmesi için enfektif formlarının (kist ve ookist) kontamine su ve yiyecekler aracılığıyla alınması gerekir. Ayrıca klorlamaya karşı son derece dirençli olan bu parazitlerin kontamine olmuş deniz, göl, ırmak ve yüzme havuzlarından bulaşabileceği bilinmektedir (Fayer, 2004; Jones ve Dubey 2010; Baque ve ark., 2011). İnsanlarda gerçekleșen sindirim sistemi enfeksiyonlarının \%35'inin patojen etkenlerle kontamine sular nedeniyle meydana geldiği belirtilmiștir (MacKenzie ve ark.,1995). Su kökenli C. parvum cryptosporidiosise, $G$. intestinalis giardiasise ve $T$. gondii toxoplasmosise sebep olmakta ve halk sağlığını tehdit etmektedir (Usluer, 2004). Herhangi bir işlem görmemiş suda T. gondii ookistlerinin 54 ay kadar yaşayabilmesi nedeniyle halk sağlığı açısından tehlikeli olabilmektedir. Ayrıca T. gondii ookistleri 10-12 $\mu$ m olup belediyelerin su filtrasyonu işlemleri sonrasında da şehir şebeke sularında tespit edilmektedir. Bu nedenle su kaynaklı toxoplasmosise bağlı salgınlar, uzun yıllardır önüne geçilemeyen önemli halk sağlığı sorunlarından biri olmuştur (Jones ve Dubey, 2010). Cryptosporidium spp. ookistleri 2-6 $\mu \mathrm{m}$ büyüklügünde olup dört sporozoit içermektedir (Fayer ve ark., 2008). Cryptosporidiosis toprağa birakılan hayvan gübreleri, direk olarak aerosol ve indirekt olarak kirli suların tüketilmesi ile ortaya çıkmaktadır (Fayer ve ark., 2000). Dokunulmamış yüzey sularında, filtre edilmiş yüzme havuzu suyunda, hatta klorlanmış veya filtre edilmiş içme sularında bile Cryptosporidium spp. ookistlerine rastlanmaktadır (Chen ve ark., 2002). Klorlamaya karşı dirençli ve enfeksiyon dozu oldukça düşük olan Cryptosporidium spp. ookistleriyle kirlenmiş yüzme havuzları, dereler ve içme suları hem insanlar hem de hayvanlar (özellikle buzağılar) için tehlike oluşturmaktadır (Ok ve Balcıoğlu, 2007). G. intestinalis'in kist formu, 11-14 $\mu \mathrm{m}$ büyüklüğündedir. Kistler dış şartlara oldukça dirençli olup nemli ortamlarda haftalarca canlı kalabilirler ve bu parazitin bulaşmasında ara konaklara gereksinimi yoktur. İnfeksiyon ağızdan kistlerin alınması ile bulaşır (Özbilgin 2006). G. intestinalis ile İlgili raporların \%90'ında protozoonun su aracılığıla, \%10'unda ise yiyecekler aracılığıyla bulaştığı belirtilmektedir (Karanis ve ark. 2007). Mikroskobik bakıda bu üç parazitin tanısında zorluklar yaşanabilmektedir. Son yıllarda, daha spesifik ve duyarlı alternatif moleküler metotlar (Polimeraz Zincir Reaksiyonu (PZR) ve antijen tanıma testleri) bu parazitlerin teşhisinde kullanılmaktadır (Cama ve ark., 2003). Cryptosporidium türlerinin genotiplendirilmesi ve zoonotik olup olmadıklarının tespitinde de en çok kullanılan yöntemler moleküler karekterizasyon yöntemleridir (Xiao, 2010). İklim özellikleri nedeniyle bol yağış alan Karadeniz Bölgesi'nde tarım ve hayvancıllı̆̆n getirdiği sosyal yapı ve çevresel koşulların yetersizliği gibi faktörler nedeniyle paraziter hastalıkların halk sağlığını tehdit ettiği saptanmıştır (Taş ve ark., 2010 ). Mevcut bu duruma rağmen, Samsun ve çevresinde su kaynaklı parazitlerle ilgili olarak yapılmış çalışmalar sınırlı sayıdadır.

Bu çalışmanın amacl, Samsun'un Terme ilçesinde bulunan Terme ve Kocaman Irmağı'ndan belirlenen altı istasyondan alınan çevre suyu örneklerinde Cryptosporidium spp., Giardia spp. ve Toxoplasma gondii'nin varlığının N-PZR ve IFA yöntemleriyle saptanmasıdır.

\section{Materyal ve Metot}

\section{Su örneklerinin toplanması ve alüminyum sülfat ile su örneklerinin çöktürülmesi}

Çalışmada Ağustos 2012-Temmuz 2013 tarihleri arasında yapılmıştır. Çalışmaya başlamadan önce Samsun ili Terme ve Kocaman Irmağı üzerinde; Köy girişi- Dere başlangıcı (K1), İki Kol Ayrımı (K2), Merkez Köprü Altı (K3), Kocaman çıkışı-Fındıklık yanı (K4), Hüseyin Mescit Köyü Merkez Köprü Altı (K5) ve Hüseyin Mescit Köyü 2. Köprü Altı (K6) olmak üzere toplam 6 farklı istasyon belirlenmiştir. Su örnekleri Samsun ili Terme ve Kocaman Irmağ üzerinde belirlenen istasyonlardan 10'ar litrelik plastik şişelerle toplanmıştır. Karanis ve Kimura'nın (2002) tanımladığı șekilde her bir su örneğinin içine $20 \mathrm{ml}$ alüminyum sülfat (Al2(SO4)3) çözeltisi eklenmiş ve pH 5.4-5.8 arasında ayarlanmıştır. Karanlık ortamda 22 saat bekleyen su örneklerinin dibinde $200 \mathrm{ml}$ kalacak şekilde üst kısımdaki sıvı kısım atılmış ve çökelti 50 ml'lik falkon santrifüj tüplerine homojen ve eșit şekilde konularak birbirini takip eden santrifüj işlemlerine tabi tutulmuştur. Altta kalan pellet daha önce hazırlanan lizis buffer tamponuyla $15 \mathrm{dk}$ 'da bir çalkalamak suretiyle bir saat inkübasyona bırakılmıștır. 


\section{Örneklerin sukroz gradiyent yöntemiyle saflaştırılması ve Ifa yöntemiyle tespiti}

Konsantre edilen su örnekleri Karanis ve Kimura'nın (2002) uyguladığı Sheather'ın şekerli yüzdürme yöntemiyle saflaştırılmıştır. Elde edilen $1 \mathrm{~mL}$ 'lik pellet ependorf tüplerine alınarak daha sonra kullanılmak üzere $-80^{\circ} \mathrm{C}^{\prime} \mathrm{de}$ muhafaza edilmiştir. Ayrıca saflaştırılan örneklerden preparatlar hazırlanmış ve IFA tekniği ile cellabs kiti kullanılarak ookistlerin fluoresan işaretli monoklonal antibadilerle boyanması sağlanmıştır. Preparatların üzerine $25 \mu \mathrm{l}$ RR2 (monoklonal antikor) eklenerek kurumaya bırakılmıștır. Daha sonra preparat üzerine tespit sivisı (mounting fluid) eklenerek floresan mikroskop altında incelenmiştir.

\section{DNA İzolasyonu ve N-PZR}

Çalışmada Sukroz gradient yöntemi ile saflaştırılan tüm su örnekleri Plutzer ve ark. (2008) ile Koloren ve ark. (2011) kullandığı protokol doğrultusunda DNA QIAamp DNA Mini Kit modifiye edilerek izolasyon yapılmıștır. PZR için Hot Start Taq DNA Polimeraz kiti (10X PZR tamponu, 5X Q solution, 25 $\mathrm{mM} \mathrm{MgCl2}$, 5U hotstart taq DNA Polimeraz), $25 \mathrm{mM}$ dNTP mix, 10 pmol türe özgü primerler ve $1 \mu \mathrm{l}$ DNA kullanılmıştır. Hazırlanan $25 \mu \mathrm{l}$ reaksiyon karışımı vortekslenip PEQlab PCR cihazında inkübasyona bırakılmıștır. T. gondii'nin 341 bç olan 18S rRNA gen bölgesi daha önce Kourenti ve Karanis'in (2004, 2006); C. parvum'un 435 bç olan 18S rRNA gen bölgesi daha önce Nichols ve arkadaşları (2003); G. intestinalis'in 292 bç olan 18S rRNA gen bölgesi daha önce Appelbee ve arkadaşları (2003), Plutzer ve arkadaşları (2008) tarafından tanımlanan protokoller modifiye edilerek çoğaltılmıştır. Elde edilen PZR ürünleri $-20^{\circ} \mathrm{C}$ 'de, kullanılıncaya kadar saklanmıștır. Her bir test için pozitif ve negatif kontroller kullanılmıștır. Oluşan ürünler ethidium bromidle boyanmıș $\% 1.5^{\prime}$ lik agara yüklenmiștir. Jel elektroforezde 100V'ta $60 \mathrm{dk}$ yürütüldükten sonra UV altında (Prizma/Quantum ST4) bantlar görüntülenmiştir.

\section{Bulgular}

Bir yılllk zaman periyodu içerisinde toplanan 72 çevresel su örneğinin 60'ında (\%83.3) 1-19 ookist/L Cryptosporidium spp. ookistlerinin, 48'inde (\%66.6) 1-13 kist/L Giardia spp. kistlerinin IFA tekniğiyle varlığı mikroskobik olarak tespit edilmiștir. Giardia spp. ve Cryptosporidium spp. pozitifliği saptanan su örneklerinin hepsi N-PZR tekniği kullanılarak doğrulanmıştır. PZR sonuçlarına göre araştırma alanında belirlenen istasyonlardan Kocaman Irmağı'ndan 5 istasyonun (K2, K3, K4, K5, K6) Cryptospordium spp. ile kontamine, 4 istasyonun (K2, K4, K5, K6) ise Giardia spp. ile kontamine olduğu belirlenmiştir. Ayrıca çalışmada alınan su örneklerinde T. gondii'nin varlı̆ğ yine N-PZR tekniğiyle araştırılmış ve Kocaman Irmağı'ndaki üç istasyonun da (K4, K5, K6) bu parazitle kontamine olduğu tespit edilmiştir. Altı farklı istasyondan alınan su örneklerine ait N-PZR ürünlerinin agaroz jeldeki görüntüleri Şekil 1,2 ve 3'te gösterilmiştir.

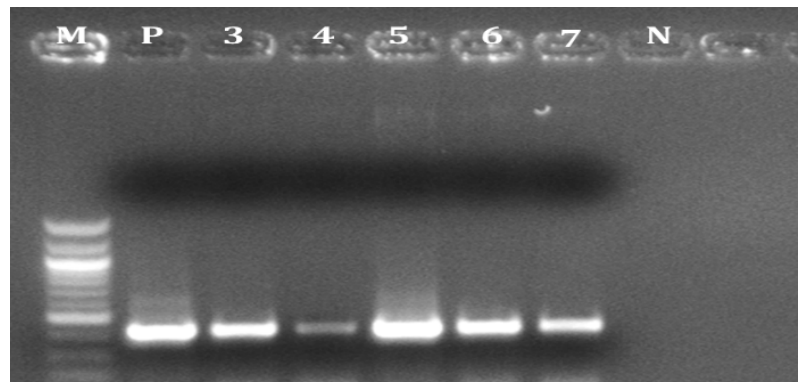

Şekil 1. Altı farklı istasyondan alınan su örneklerine uygulanan N-PZR ürünlerinin agaroz jeldeki görüntüsü. M: 100-bç DNA marker; N: distile su (negatif), P: Cryptosporidium IOWA DNA'sı (pozitif); 3-7 kuyucuk doğadan alınan su örnekleri.

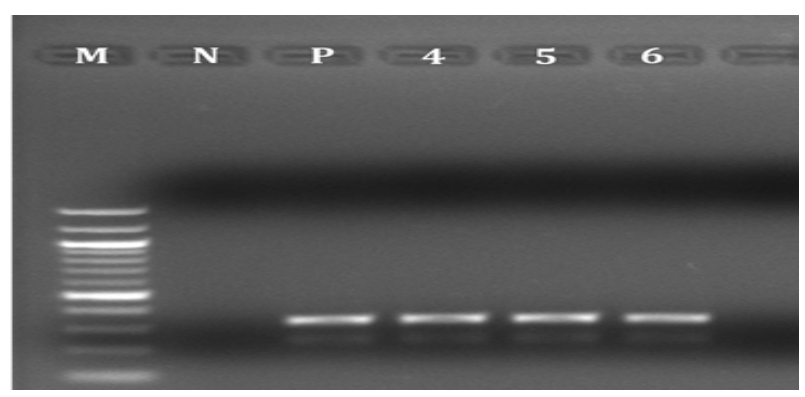

Şekil 2. Altı farklı istasyondan alınan su örneklerine uygulanan N- PZR ürünlerinin agaroz jeldeki görüntüsü. M: 100-bç DNA marker; N: distile su (negatif), P: Toxoplasma AHC1 (oocysts) DNA; 46 kuyucuk doğadan alınan su örnekleri.

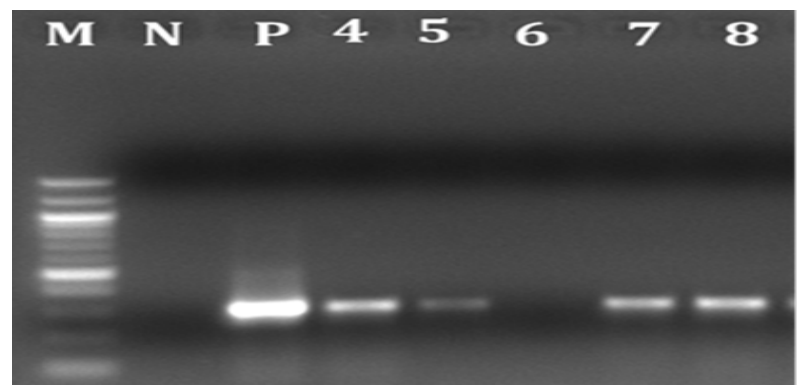

Şekil 3. Altı farklı istasyondan alınan su örneklerine uygulanan N-PZR ürünlerinin agaroz jeldeki görüntüsü. M: 100-bç DNA marker; N: distile su (negatif), P: Giardia H3 DNA'sı (pozitif); 4-8 kuyucuk doğadan alınan su örnekleri. 


\section{Tartışma ve Sonuç}

Sular, bakteri, virüs ve parazitlerle enfekte hayvan ve insanların dışkıları ile kirlenebilmektedir. $\mathrm{Bu}$ hastalık etkenleri, enfekte sular ile doğrudan veya dolaylı yollarla konağı enfekte edebilmektedir (Uslu ve Türkman, 1987; Alkan ve ark., 1999). Son yıllarda su kaynaklı parazit salgınlarının artış göstermesi bu alanda yapılan çalışmalara daha fazla önem verilmesine neden olmuştur. Türkiye'de su kaynaklı Cryptosporidium spp., Giardia spp. ve T. gondii hakkında oldukça sınırlı sayıda çalışma mevcuttur. Ulaşılan kaynak bilgilere göre 2002 yıllarında Mayıs ve Haziran aylarında 43 şebeke suyu, 34 kuyu suyu, 6 irmak suyu ve 2 baraj suyu olmak üzere toplam 85 su örneğinde Cryptosporidium spp. MAF, Trikrom boyama ve PZR yöntemleriyle araştırılmıștır. Altı ırmak suyundan 1'i (\%16.6) PZR yöntemiyle pozitif olarak bulunmuştur (Bakir et al., 2003). Çeber ve ark. (2005) tarafindan, Mersin ilinden alınan musluk, kuyu, deniz ve kanalizasyon olmak üzere toplam 100 su örneğinde Cryptosporidium spp. ookistleri araştırılmıştır. İçme sularında 5 (\%11.36), kuyu sularında 1(\%50), deniz suyu örneklerinde 1 (\%2.85), atık sularında 4 (\%21) örnekte Cryptosporidium ookisti saptanmıştır. Koloren ve Delioglu (2011) Modifiye Acid-Fast (MAF) yöntemiyle Amasya ilinde Cryptosporidium spp.'nin prevalansını belirlemişlerdir. Alınan 100 su örneğinin 78'inde (\%78) Cryptosporidium spp. ookisti pozitif olarak bulunmuştur. On içme suyu örneğinde Cryptosporidium ookistine rastlanmazken 90 irmak suyu örneğinin 78 'inde (\% 86.66) bu parazite rastlanmıştır. Koloren ve arkadaşları (2011) İlmiğe dayalı izotermal amplifikasyon (LAMP) ve IFA yöntemleri ile Ordu ilinde Cryptosporidium spp.'yi araștırmışlardır. Çalışmada alınan 70 su örneğinin 8 'inde (\%25.7) LAMP yöntemiyle, 19'unda (\%27.1) ise IFA yöntemiyle Cryptosporidium spp. ookisti tespit edilmiştir. Koloren ve arkadaşları (2012) tarafından Sinop ilinden alınan 48'i deniz suyu, 10'u içme suyu olmak üzere toplam 58 su örneğinde MAF yöntemiyle Cryptosporidium spp. ookistleri araştırılmıştır. Alınan su örneklerinin 46'sında (\%79.31) 2-46 ookist/L arasında değişen oranlarda ookist görülmüştür. Son ylllarda, Samsun ve Giresun illerinde sekanz analizleriyle Giardia spp. (Koloren ve ark., 2016) tespit edilmiştir. Çalışmada beş örnek Giresun ilinden, 10 örnek Samsun ilinden $G$. duodenalis assemblage $\mathrm{B}$; yine beş örnek Giresun ilinden, beș örnek Samsun ilinden G. duodenalis assemblage A olarak genotiplendirilmiștir. Samsun ve Giresun illerinde sekanz analizleriyle Cryptosporium spp. Koloren ve Ayaz, (2016) tarafından tespit edilmiştir. Samsun ilinden alınan beş örneğin Cryptosporidium bovis, altı örneğin Cryptosporidium parvum ve bir örneğin ise Cryptosporidium felis olduğu bulunmuştur. Giresun ilinde bir örneğin C. bovis, beş örneğin ise C. parvum olduğu tespit edilmiştir. Koloren ve Ayaz (2016), Koloren ve arkadaşlarının (2016) yapmış oldukları çalışmalar Samsun ve Giresun illerinde su kaynaklı Cryptosporidium spp ve Giardia spp.'nin genotiplendirmesine ait ilk çalışmalardır. T. gondii'yi Kolören ve Demirel (2013a) Amasya'dan alınan 120 çevre suyu ve 20 içme suyu N-PZR yöntemiyle araştırmışlardır. Çalışmada kırk sekiz çevre suyu örneğinde (\%40) T. gondii'ye Yine Kolören ve Demirel (2013b) başka bir çalışmalarında ırmak, göl ve şebeke sularından alınan su örneklerinde LAMP yöntemiyle $T$. gondii'nin varlı̆̆ını göstermişlerdir. Araştırmacılar elli altı su örneğinin 20'sinde (\%35.7) LAMP yöntemiyle, 16'sında (\%21.42) N-PZR ile ve 12 'sinde (\%28.57) standart PZR ile T. gondii'nin varlığını tespit edilmiştir etmişlerdir. Demirel ve arkadaşları (2014) tarafından Giresun'dan alınan su örneklerinde LAMP ve PZR yöntemleriyle $T$. gondii' nin varlığı araştırılmıştır. Çalışmada 76 çevre suyu örneğinin 10'unda (\%13.2) T. gondii DNA pozitifliği her iki yöntem ile tespit edilmiştir. Alınan 20 içme suyu örneğinde bu parazite rastlanılmamıştır. $\mathrm{Bu}$ çalışmada ise alınan 72 çevresel su örneğinin 60'ında (\%83.3) 1-19 ookist/L Cryptosporidium spp. ookistleri ve 48'inde (\%66.6) 1-13 kist/L Giardia spp. kistleri IFA ile pozitif olarak bulunmuştur. IFA yöntemi ile pozitif bulunan su örneklerinin hepsi N-PZR tekniği ile de doğrulanmıştır. Bu çalışmada ise daha önce Ordu, Giresun ve Samsun illerinde yapılan çalışmalar göz önünde bulundurularak paraziter etkenlerle kontamine olma ihtimali yüksek olan Terme ilçesinde altı istasyon belirlenip, su kaynaklı $T$. gondii, Cryptosporidium spp. ve Giardia spp.'nin yaygınlığı araştırılmıştır. Çevresel sularda $T$. gondii'nin tanımlanması hala günümüzde problemlidir. Mikroskop temelli, hücre kültürü çalışmaları ve moleküler metodlar, sudaki protozoonların tespiti için tercih edilen yöntemlerdir. Ancak immün magnetik ayırma (IMS) teknikleri ve immünofloresan boyama yöntemleri hala T. gondii ookistleri için standardize edilememiştir. $\mathrm{Bu}$ nedenle T. gondii ookistleri ve sporokistlerinin ayırt edilmesinde IMS tekniği yeterli olamamaktadır. Ayrıca IMS kitinin antikorları $T$. 
gondii ile Hammondia hammondi ve Neospora caninum gibi parazitlerin sporokistleri arasında çapraz kontaminasyona neden olmaktadır. Ancak gene spesifik primerlerin kullanıldığı PZR yöntemlerinde IMS'te olduğu gibi herhangi bir çapraz kontaminasyon olmadığ için suda mevcut olan diğer inhibitörlerden de etkilenmemektedir. Yine bu yöntemle kültüre gerek duyulmaksızın çok kısa zamanda sonuç alınabilmektedir (Dumetre ve Darde, 2007; Schares ve ark.., 2008; Koloren ve Demirel 2013b). Çalışmamızda da benzer olarak $T$. gondii'nin tespiti için N- PZR yöntemi kullanılmış ve üç istasyonda parazit tespit edilmiştir. Sulardan Cryptosporidium spp. ve Giardia spp'nin tespitinde, konsantrasyon için IMS yöntemi, ookist/kistlerin tanımlanmasında ise IFA yöntemi standart yöntemler olarak belirtilmektedir. Ancak her iki yöntem de bu parazitlerin karakterizasyonu için yeterli değildir (USEPA, 2005; Baque ve ark., 2011). Parazitlerin karakterizasyonu için IMS yönteminin moleküler yöntemlerle desteklenmesi gerektiği bildirilmiştir. PZR yönteminin IMS yöntemiyle kombine kullanıldığı zaman daha güvenilir ve daha hızlı sonuçlar alınabildiği bildirilmiștir (HallierSoulier ve Guillot, 2000). Parazitlerin tanımlanmasında özellikle N-PZR ile olası bir kontaminasyon riski, tekrar çoğaltılan PZR ürünü ile en aza indirildiği için daha etkili tanı konulabildiği belirtilmiştir (Minarovicova ve ark., 2009). Bu doğrultuda çalışmada da araştırma alanındaki Cryptosporidium spp. ookistlerinin ve Giardia spp. kistlerinin tespiti için IFA tekniğinin yanı sıra N-PZR tekniği kullanılmıştır. IFA ile pozitif bulunan tüm örnekler N-PZR ile çalışılmıştır. Bu yöntemle daha kısa sürede ve herhangi bir kontaminasyon sorunu yaşanmadan güvenilir sonuçlar elde edilmiştir. Çalışmamızda, belirlenen istasyonlarda Cryptosporidium spp., Giardia spp. ve T. gondii tespit edilmiş olup paraziter etkenlerle kontamine olmuş suların, çevrede yaşayan insan ve hayvanlar için bir risk faktörü olduğu sonucuna varılmıştır. Yağış oranı yüksek olan bölgemizde paraziter etkenlerin yayılmasını kolaylaştıran dere gibi su kaynaklarının içme suyu olarak kullanılması dikkate alınarak gerekli önlemlerin alınması ve güvenli su kullanımı konusunda halk sağlığı eğitimlerinin yapılması uygun olacaktır. Ayrıca fekal-oral yolla bulaşan su kökenli parazitlerin bulaşma riskini azaltmak amacıyla su kaynaklarının düzenli bir șekilde kontrol edilmesi ve Üniversite ve Sağlık Bakanlığı'nın ilgili birimlerinin iş birliği ile gerekli tedbirlerin alınmasının uygun olacağı kanaatine varılmıştır.

\section{Kaynaklar}

Alkan, U., Çalışkan, S., Mescioğlu, Ü. 1999. Ulubat Gölü' nün Mikrobiyolojik Kirlilik Seviyesinin Belirlenmesi. Çevkor, 9 (33): 3-5.

Appelbee, A.J., Frederick, L.M., Heitman, T.L., Olson, M.E., 2003. Prevalence and genotyping of Giardia duodenalis from beefcalves in Alberta, Canada. Veterinary Parasitology. 112: 289-294.

Bakir, B., Tanyuksel M., Saylam F., Tanriverdi S., Araz E.R, Hacim A.K., Hasde M. 2003. Investigation of Waterborne Parasites in Drinking Water Sources of Ankara, Turkey. The Journal of Microbiology, 148151.

Baque, R.H., Gilliam, A.O., Robles, L.D., Jakubowski, W., Slifko, T.R. 2011. Areal-time RT-PCR method to detect viable Giardia lamblia cysts inenvironmental waters. Water Research, 45: 3175-3184.

Cama, V.A., Bern, C., Sulaıman, I. M., Gılman, R. H., Ticona, E., Vıvar, A., Kawaı, V., Vargas, D., Zhou, L., Xıao, L. 2003. Cryptosporidium species and genotypes in HIV-positive patients in Lima, Peru. The Journal of Eukaryotic Microbiology, 13: 531-533.

Çeber, K., Aslan, G., Otağ, F., Deli-alioğlu, N., Öztürk, C., Babür, C., Emekdaş, G. 2005. Mersin ilinde içme suyu, kullanma suyu, atık su ve deniz sularında Cryptosporidium spp. ookistlerinin araștırılması. Türkiye Parazitoloji Dergisi, 29: 224-8.

Demirel, E., Kolören, Z., Karaman, Ü., Ayaz E. 2014. Investigation on Toxoplasma gondii by Polymerase Chain Reaction and Loop-Mediated Isothermal Amplifi cation in Water Samples from Giresun, Turkey. Bulletin of Microbiology, 48(4): 661-668.

Demirel, E., Kolören, Z. 2012. Ordu İli Melet Irmağı'ndan alınan su örneklerinde Toxoplasma gondii yaygınlığının nested PCR ile tespiti. 21. Ulusal Biyoloji Kongresi, 3-7 Eylül 2012, İzmir. Kongre Kitabı, s: 1353

Dumetre, A., Darde, M. L. 2007. Detection of Toxoplasma gondii in Water by an Immunomagnetic Separation Method Targeting the Sporocysts. Parasitology Research, 101: 989-996.

Fayer, R. 2004. Cryptosporidium: a water-borne zoonotic parasite. Veterinary Parasitology, 126: 37-56.

Fayer, R., Santin, M., Trout, J.M. 2008. Cryptosporidium ryanaen spp. (Apicomplexa: Cryptosporidiidae) in cattle (Bos taurus). Veterinary Parasitology, 156: 191-198.

Hallier-Soulier, S., Guillot, E. 2000. Detection of cryptosporidia and Cryptosporidium parvum oocysts in environmental water samples by immunomagnetic separation-polymerase chain reaction. Journal of Applied Microbiology. 89: 5-10. 
Jones, J. L., Dubey, J. P. 2010. Waterborne ToxoplasmosisRecent Developments. Experimental Parasitology. 124: 10-25.

Karanis, P., Kimura, A. 2002. Evaluation of three flocculation methods for the purification of Cryptosporidium parvum oocysts from water samples. Letters in Applied Microbiology, 34:444449.

Karanis, P., Oriel, T., Klytaimnistra, K., Jerry, O., Ikuo, I., Noborou, I. 2007. Development and preliminary evaluation of a loop-mediated isothermal amplification procedure for sensitive detection of Cryptosporidium oocysts in fecal and water samples. Applied Environmental Microbiology, 73: 56605662.

Koloren Z., Avşar C., Kaya D., 2012. Monitoring of Cryptosporidium Species in Water Supplies of Sinop, Black Sea, Turkey by Acid-Fast Staining Method. Journal of Applied Biological Sciences, 6 (3): 41-43.

Koloren Z., Delioglu B.K. 2011. Prevalence of Cryptosporidium species in water supplies of Amasya, Middle Black Sea, by Acid-Fast staining methods. Journal of Applied Biological Sciences, 5, 81-84.

Koloren Z., Karanis P., Sotiriadou I. 2011. Investigations and Comparative Detection of Cryptosporidium Species by Microscopy, Nested PCR and LAMP in Water Supplies of Ordu, Middle Black Sea, Turkey. Annals of Tropical Medicine and Parasitology, 105, 607-615.

Koloren, Z., Ayaz, E. 2016. Genotyping of Cryptosporidium spp. in environmental water in Turkey. Acta Parasitologica, 61(4), 671-679.

Koloren, Z., Demirel, E. 2013a. Investigation on Toxoplasma gondii in surface and drinking water samples from Amasya by nested polymerase chain reaction. Journal of Applied Biological Sciences, 7(2): 10-3.

Koloren, Z., Demirel, E. 2013b. Detection of Toxoplasma gondii in Turkish river and drinking water samples by different PCR and LAMP Methods. Clean Soil Air Water, 41(10): 963-8.

Koloren, Z., Seferoğlu, O., Karanis,P. 2016. Occurency of Giardia duodenalis assemblages in river water sources of Black Sea, Turkey. Acta Tropica, 164:337-344.

Kourenti, C., Karanis, P. 2004. Development of a Sensitive Polymerase Chain Reaction Method for the Detection of Toxoplasma gondii in Water. Water Science and Technology, 50, 287-291.

Kourenti, C., Karanis, P. 2006. Evaluation and Applicability of a Purification Method Coupled with Nested PCR for the Detection of Toxoplasma Oocysts in Water, Letters in Applied Microbiology, 43: 475-481.

MacKenzie, W.R., Kazmierczak, J.J., Davis, J.P. 1995. An outbreak of cryptosporidiosis associated with a resort swimming pool. Epidemiology and Infection, 115: 545-553.

Minarovičova', J., Kaclı'kova', E., Krascsenicsova', K., Siekel P., Kuchta T. 2009. A single-tube nested real-time polymerase chain reaction for sensitive contained detection of Cryptosporidium parvum. Letters in Applied Microbiology. 49: 568-572.

Nichols R.A.B., Campbell B.M., Smith H.V. 2003. Identification of Cryptosporidium oocysts in United Kingdom noncarbonated natural mineral waters and drinking waters by using a modified nested PCR-restriction fragment length polymorphism assay. Applied and Environmental Microbiology, 69: 4183-4189.

Ok, Ü.Z., Balcioğlu, İ.C. 2007.Cyrptosporidiosis. Tıbbi Parazit Hastalıkları. Ed.: M.A. Özcel. İzmir: Türkiye Parazitoloji Derneği Yayın No:22., s.: 363-377.

Özbilgin, A. 2006. Barsak Protozoonları. Ankem Dergisi, 20(2): 166-169.

Plutzer, J., Karanis, P., Domokos, K., Torokne, A., Marialigeti, K. 2008. Detection and characterization of Giardia and Cryptosporidium in Hungarian raw, surface and sewage water samples by IFT, PCR and sequence analysis of the SSUrRNA and GDH genes. International Journal of Hygiene and Environmental Health, 211, 524-533.

Schares, G., Herrmann, D. C., Beckert, A., Schares, S., Hosseininejad, M., Pantchev, N., Vrhovec, M. G., Conraths, F. J. 2008. Characterization of a Repetitive DNA Fragment Hammondia hammondi and Its Utility for the Specific Differentiation of $\mathrm{H}$. hammondi from Toxoplasma gondii by PCR. Molecular and Cellular Probes, 22: 244-251.

Taş, B., Candan, A.Y., Can, Ö., Topkara, S. 2010. Ulugöl (Ordu)'ün bazı fiziko-kimyasal özellikleri. Journal of Fisheries Sciences, 4 (3): 254-263.

USEPA, 2005. USEPA Method 1623: Cryptosporidium and Giardia in Water by Filtration/IMF/FA. Office of Water, Washington, D. C. EPA 815-R-05.Uslu, O., Türkman A. 1987. Su Kirliliği ve Kontrolü, T.C.Başbakanlık Çevre Genel Müdürlüğü Yayınları Eğitim Dizisi 1, İzmir, 364.

Uslu O., Türkman, A.1987. Su kirliiği ve kontrolü, TC Başbakanlık Çevre Genel Müdürlüğü yayınları eğitim dizisi, 365

Usluer. G. 2004. Su ile bulașan enfeksiyonlar. Ankem Derg, 18: 17-20.

Xiao L. 2010. Molecular epidemiology of cryptosporidiosis: an update. Experimental Parasitology, 124: 80-89. 